\title{
Tina $\mid$ ETRUŠČANSKI JEZIK SILIČ KOT POSREDNIK PRI PREVZEMANJU GRŠKIH BESED V LATINŠČINO
}

Izvleček

Nekatere grške izposojenke so v latinščini preoblikovane na način, ki ga $\mathrm{z}$ latinskimi jezikovnimi zakonitostmi ne moremo razložiti, zato predvidevamo posrednika. S preučevanjem sprememb, ki so doletele ohranjene grške besede v etruščanskem jeziku, se skuša dognati določene vzorce, s pomočjo katerih bi lahko razložili nenavadno obliko izposojenke v latinščini.
Abstract

A number of Greek words imported into Latin are modified in ways which cannot be explained by the properties of either language, thus suggesting an intermediary. The article examines the modifications of Greek words in the Etruscan language, attempting to determine patterns which could explain the unusual forms of the same loan words in Latin.

\section{Uvod}

Ko so Grki začeli kolonizirati srednjo in južno Italijo ter Sicilijo v sredini 8. st. pr. n. št, so bili na Apeninskem polotoku Etruščani na vrhuncu razvoja. Njihov vpliv je segal od Lacija na jugu do Padske nižine na severu. Naseljevalci, ki so vsekakor sledili predhodnim trgovskim stikom, so izhajali iz različnih narečnih skupin. Ustalili v južni Italiji in na Siciliji. S svojim neizčrpnim zanosom in višjo kulturno stopnjo so bili bogat vir za vsa ljudstva v Italiji. Njihov vpliv ni očiten le na gospodarskem področju, ampak tudi v religiji, mitologiji in jeziku.

Živahne stike med Grki in Etruščani nam dokazujejo številni zgodaj prevzeti izrazi za posode in druge obrtniške izdelke ter izrazi iz pomorskega in zemljemerskega žargona. Iz etruščanske umetnosti je razvidno, da so poznali mnogo figur iz grškega panteona in mitologije že kmalu po letu 600 pr. n. št. (Demetro, Dioniza, Hermesa, Apolona in druge). Pisavo so Etruščani prevzeli od kolonizatorjev z Evboje, ${ }^{1}$ ki so govorili jonsko-atiško narečje, pisali pa halkidiško različico zahodnogrškega alfabeta.

Ker v času kolonizacije in zgodnje republike tesnejših neposrednih

${ }_{1}$ V 8. st. pr. n. št. so ustanovili Kume v Kampaniji ter Pitekuzo (dan. Ischia). 
stikov med samim Rimom in grškimi mesti ni bilo, moramo upoštevati, da so prvotni elementi grške kulture in njihovo besedišče prihajali v Rim preko posrednikov-Etruščanov. S pomočjo filoloških kriterijev lahko razlikujemo med kronološkimi in narečnimi razlikami grških izrazov ${ }^{2}$ in veliko izvemo tudi o razvoju etručanskega jezika. ${ }^{3}$ Posredovanje se kaže v vrsti značilnosti, $\mathrm{v}$ glavnem spreminjanju vokalov ter zvenečih zapornikov.

Glavni znaki, ki jih pripisujemo etruščanskemu posredovanju, so:

1. Sprememba vokala o: Etrurščani niso imeli glasu $o$ in so grške $\boldsymbol{\omega}$, ○ ter kratki in dolgi $u$ izgovarjali kot $\boldsymbol{u}$ in zapisovali z isto črko $(\Upsilon$ kasneje V) ${ }^{4}$ ki se v nekaterih primerih ohrani še v latinščini.

2. Zamenjava zvenečih zapornikov z nezvenečimi: gr. $\beta, \delta, \gamma>$ lat: p, t, c

3. Izpad sredinskih zlogov: okoli leta 500 pr. n. št. je prišlo do spremembe naglasa. Besede so se začele izrazito naglaševati na prvem zlogu. V sredinskih zlogih, ki niso bili naglašeni, so začeli samoglasniki šibeti in izpadati (sinkopa). Razlike so zelo očitne med starejšimi in mlajšimi napisi. Imena kot 'A $\lambda \hat{\varepsilon} \xi \alpha \nu \delta \rho \circ$ in K $\lambda u \tau \alpha \iota \mu \hat{\gamma} \sigma \tau \rho \alpha$ postanejo $A l$ csentre, nato še krajšse Elcsntre ter Clutumsta, Clutmsta. Tudi samoglasniki v končnih zlogih večkrat odpadejo.

4. Spremembe v končnih zlogih: Grške izposojenke so se vključile v etruščanski morfološki sistem, končnice so se prilagodile. ${ }^{5}$ Kot etruščanske prvine pri latinskih izposojenih samostalnikih pridejo $\mathrm{v}$ poštev:

-na: je načeloma pridevniška končnica, vendar jo dobimo tudi pri imenih in samostalnikih: Macstrna (< lat. magister) in malena 'ogledalo'.

2 Jonsko - atiška skupina se razlikuje od ostalih predvsem po spremembi dolge $\alpha$

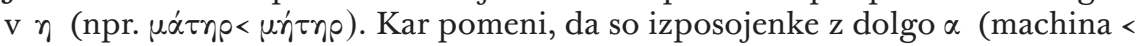
$\mu \bar{\alpha} \chi \alpha \nu \alpha ́$ ) iz dorskega okolja. Po časonvem kriteriju je koristen kazatelj tudi raba digame; v jonsko-atiških narečjih je izginila pred obdobjem najstarejših napisov, medtem ko se je v nekaterih dorskih narečjih ohranila dlje, razen med samoglasnikoma - zatorej besede kot oliva < $\dot{\varepsilon} \lambda \alpha i f \alpha$ pripisujemo zelo staremu prevzetju.

3 Preučevanje grških izposojenk v etrurščini prineslo velik napredek zlasti na področju glasoslovja.

4 Zanimiva je primerjava s t. i. Lemnoškim napisom, ki kaže presenetljive podobnosti z etruščanskim jezikom: odsotnost vokala $u$ (v etr. $o$ ) in zvenečih zapornikov, nekaj podobnih obrazil za označevanje starosti in letnic.

5 Več v naslednjem poglavju. 


\section{-tre (-tra)}

Od teh glavnih razpoznavnih znamenj lahko izpostavimo še nekatere pogoste spremembe, ki jih bomo sicer natančneje opisali na posameznih primerih: $c r<\gamma \nu, t r<\delta \nu, f t<\pi \tau$.

To so pozitivni kriteriji oziroma kazatelji. Več primerov pa je potrebno obravnavati po negativnih kriterijih, kar pomeni, da so v latinščini oblike izposojenk, ki jih z latinskim glasovnim sestavom ne moremo razložiti, zato se ugotavlja, če se ravnajo po etruščanskem.

\section{Obravnava grških glasov v etruščanskem jeziku}

Ohranjeni napisi kažejo, da je največ izposojenk prišlo v etruščanski jezik iz dorskih narečij in sicer so pri tem največjo vlogo igrali korintski obrtniki iz kolonij v južni Italiji. Samo med lastnimi in krajevnimi imeni je 30 dorskih, medtem ko je iz jonsko-atiških narečij 15 imen. Nekatera imena pa imamo ohranjena v več različicah, vzetih iz različ-

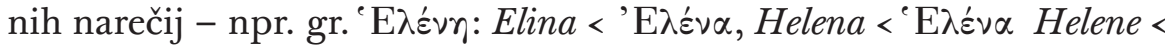
${ }^{~} E \lambda \varepsilon ́ v \eta$ slednja je najpoznejša, iz helenističnega obdobja, prvi dve pa nista iz jon.-at. okolja.

\section{Dorski sklad:}

Dolgi $\alpha$ iz dorskih narečij je vedno zastopan z etruščanskim $a$, ki je skupaj z digamo glavni kazatelj dorskega izvora izposojenke. Seveda je pri besedah, kjer se dolgi a niti v jon. - at. narečjih ne spremeni v eto (npr. za $\rho, \iota, \varepsilon$ ), potrebno iskati druge kazatelje.

Digama se v glavnem ohrani na začetku besede, saj v položaju med samoglasnikoma tudi iz dorskih narečij prej izgine. Tako pri imenih

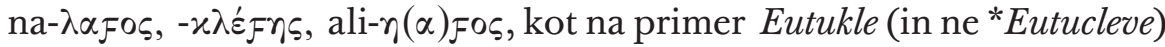

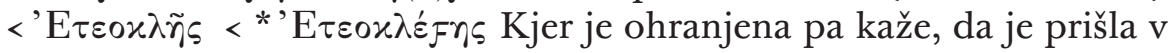

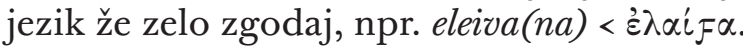

Jonski sklad:

Jonska eta je v etrurščini predstavljena z $e$ ali $i$ - v mlajši etrurščini,

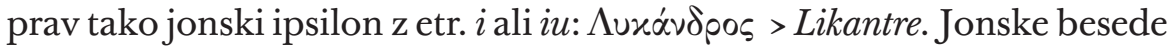
so sprva $\mathrm{k}$ Etruščanom prihajale iz halkidiških kolonij v Kampaniji in na Siciliji, več pa jih je poznejših, iz helenistične dobe.

Najpogostejši vzorci, po katerih so se grške besede prestavljale v etruščanski jezik: 
1. Začetni zlogi:

- samoglasniki se $\mathrm{v}$ začetnih zlogih navadno ohranijo: dolga in kratka $\alpha>$ a; $\varepsilon$ in $\eta>$ e; dolga in kratka $\iota>\mathrm{i}$; dolgi in kratki $u$ ter 0 , $\omega>\mathrm{u}$

- dvoglasnik al se sprva še ohrani kot ai, vendar se postopoma poenostavi ai > ei > e zaradi začetnega naglasa (prim. Aivas, 5. st.; Eivas,

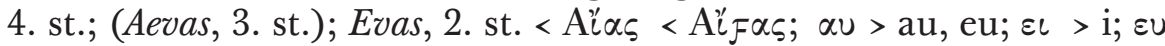
$>$ eu, ev; or > ui;

- samoglasniške skupine: $\alpha 0>\mathrm{a} ; \varepsilon_{0}>\mathrm{e}, \mathrm{eu} ; \omega \iota>\mathrm{ui} ; \iota \alpha>$ ea, eia; เo > i (u);

\section{Sredinski zlogi:}

Od 5. st. pr. n. št. naprej imamo vse več primerov izpada samoglasnika, ki najbolj prizadene kratke samoglasnike tako v odprtih kot zaprtih sredinskih zlogih. Obdobje petega stoletja je sicer še prehodno, v mlajši etrurščini pa so spremenjene vse besede.

Kratka $\alpha$ (preko vmesne stopnje $u$ ) izpade; dolga $\alpha$ se ohrani kot $\mathrm{a} ;{ }^{6} \varepsilon>/($ preko $i$ in $e$ ), nekaj primerov tudi $\mathrm{z}$ a ali e; $\eta>\mathrm{e}$ in $\mathrm{i} ; 0>$ $/, \mathrm{u} ; \omega>\mathrm{u}, \mathrm{a} ;$ kratka $\iota$ in $\mathrm{v}$ glavnem izpadeta, dolga pa ostaneta kot $\mathrm{i}$ in $\mathrm{u}$.

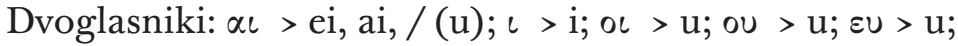

Samoglasniške skupine: $\varepsilon 0>\mathrm{u} ; \iota \alpha>\mathrm{ia}$, ea, $\mathrm{a} ; \varepsilon \alpha>\mathrm{ia}, \mathrm{a} ; \iota \mathrm{co}$ iu, a; vo $>\mathrm{u} ; \eta_{e}>\mathrm{i}$.

\section{Končni zlogi}

-o૬ > -e: grški samostalniki debla na -o so v etrurščini največkrat zastopani s končnico $-e$. Nekaj primerov tudi na - $u$ in $-a$ (lastna imena in priimki, tudi enodelna suženjska imena ter imena bogov in grških herojev).

- $\delta$ po > -te : najbrž je obstajala končnica - te, -e, saj imamo ohranjenih veliko imen, ki se končujejo tako;

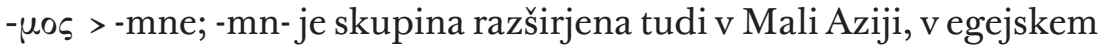
prostoru in na Balkanskem polotoku. V etrurščini jo najdemo zlasti v rodovnih imenih: Velimna,...

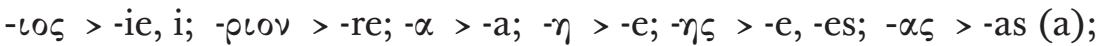

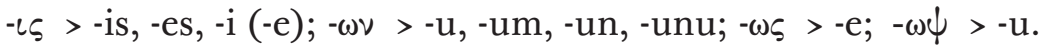

${ }^{6}$ Ohrani se kot ai: Zimaite < $\Delta \iota u_{n} \dot{\delta} \delta$ s; za to imamo sicer le dva izpričana primera, ki bi lahko utemeljila etruščansko posredovanje pri scaena $<\sigma x \alpha \nu \alpha$, saj imamo na latinskem napisu ohranjeno tudi obliko SCAINA (CIL I $\left.{ }^{2} 1794\right)$. Vendar sta morda obliki le posledica hiperetruskicima - reakcija na poenostavljanje dvoglasnikov zaradi začetnega intenzitetnega naglasa. 


\section{Soglasniki}

- digama kot v; večkat je ohranjena v začetnih zlogih kot notranjih, saj se je tudi v grščini dlje ohranila na začetku besede;

- ostri pridih največkrat $\mathrm{z}$ eto; tako ostri pridih kot digama nista vselej dosledno zapisana, včasih ju izpustijo, včasih dodajo, kjer ju ne bi pričakovali.

- zaporniki so se najobčutneje spreminjali, ker etrurščina ni poznala zvenečih zapornikov:

$-\beta, \pi>p$

$-\tau, \delta>\mathrm{t}$

$-\chi, \gamma>\mathrm{q},{ }^{7} \mathrm{k}, \mathrm{c}$ (na najstarejših napisih še najdemo vse tri črke za isti glas, kasneje pa je v južnih predelih prevladala gama (c), v severnih pa kapa (k). Pridihnjeni zaporniki se ohranijo.

\section{- zaporniki v skupinah}

V stiku z zvočniki ali s priporikom (bodisi pred ali za), se nezveneča zapornika $t$ ter $k$ pridihneta: $\lambda, \rho, \mu, \nu, \sigma+\tau, x<\mathrm{th}, \mathrm{kh}$;

$-\gamma \nu>\mathrm{cn}>\mathrm{cr}^{8}$

$-\delta v>\operatorname{tn}>\operatorname{tr}$

$-x \tau>\chi \mathrm{t}>\mathrm{t}$

$-\pi \tau>\mathrm{ft}>\mathrm{t}$

- dvojni konzonant se je v etrurščini zapisoval z dvema črkama: cs, ks $>\chi$ s (po aspiraciji). Oblika Herkle je posebnost. Po izpadu alfe med $l$ in $r$, se je vrinil $k$, ki pa se ni pridihhnil.

- dvojnih soglasnikov v etruščanskem jeziku ni zapisanih, zato jih poenostavijo tudi v grških in latinskih imenih.

\section{Analiza posameznih izposojenk}

V navedenih primerih se ugotavljajo sledi etruščanskega posredovanja po omenjenih glasovnih kriterijih, vendar ostaja $v$ mnogih primerih še veliko odprtih vprašanj. Za večino besed etruščanska vmesna stopnja ni ohranjena in jo le predvidevamo, zato moramo biti pri zaključkih previdni.

Možno je etruščansko posredovanje po naslednjih kriterijih:

1. Po spremembah samoglasnikov $v$ začetnih zlogih

- gr. kratka $u, 0$ > etr. $\mathbf{u}>$ lat. o; gr. $\omega$ > etr. $u$ > lat $o$ / u

Čeprav so v etrurščini vsi glasovi zapisani z isto črko, je razlika

7 qje ohranjen le trikrat pri besedi qutun.

8 Sprememba ne poteka v priimkih latinskega izvora: Cnaive < lat. *Gnaivos in Cnare < lat. *Gnarus. 
v izgovorjavi grških dolgih in kratkih vokalov verjetno bila, saj se v latinskih izposojenkah dolžina ohrani. Poleg tega se kratki o in u najpogosteje spet povrneta v kratki o, medtem ko je za gr. $\omega$ opaziti nihanje med $u$ in $o$.

- gr. o: lat. o:

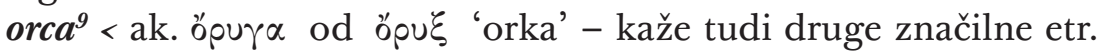
spremembe (izpad sredinskega samoglasnika in sprememba zvenečega zapornika v nezveneči);

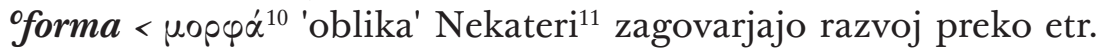
oblike *murpha > *murma (po asimilaciji $m-p h>m-m$ ), nato bi šel razvoj v latinščini v forma, kakor formica $<\mu o ́ p \mu \eta \xi ;$

- gr. $\boldsymbol{\omega}$ : lat. $\mathbf{u} / \mathbf{o}$

'cuneus < $\gamma(\dot{\omega} v$ เos 'klin'12 preko etr. *cunie

'cupa $<$

groma, gruma < $\gamma \nu \tilde{\omega} \mu \alpha$ 'zemljemerska naprava'. Pojavlja se v obeh različicah, vendar nosi tudi druge znake etr. posredovanja; $;^{13}$

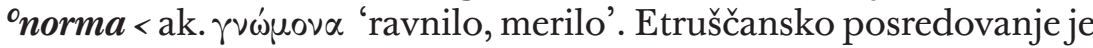

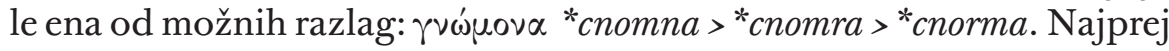

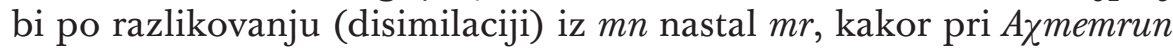

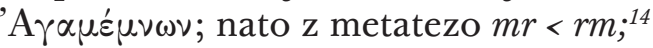

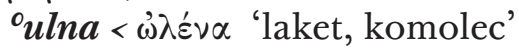

- gr. kratki u : lat. o

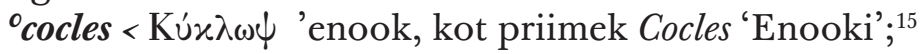

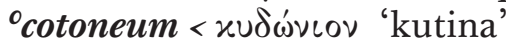

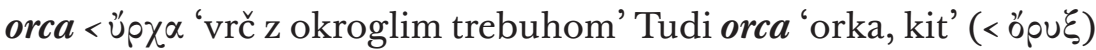
nosi etruščanske sledi, kajti $o\left(<\right.$ etr. $u$ ) ustreza grškemu o. Pri Pavlu ${ }^{16}$ imamo ohranjen citat, ki izvor imena za vazo naveže na okroglost tega morskega sesalca: 'genus marinae beluae maximum, ad cuius similitudinem vasa ficaria dicuntur'. Tudi pri Walde-Hofmannu najdemo razlago, da nezveneči zapornik namesto zvenečega ni vpliv etruščanskega posre-

9 Prim orca < üpxa.

${ }^{10} \mathrm{~S}$ krožcem so označene besede, pri katerih se kažejo le nekatere etr. značilnosti, ni pa nujno posredovanje.

${ }^{11}$ E. Benveniste, L. R. Palmer.

${ }^{12} \mathrm{Pri}^{\circ}$ cuneus in ${ }^{\circ}$ crumina (crumena) v prvem zlogu ostane $\mathrm{u}$, vendar je v latinščini kratek.

${ }^{13}$ Več v nadaljevanju.

${ }^{14}$ A. Ernout.

${ }^{15}$ Več v nadaljevanju.

${ }^{16}$ Ex Festo 195, 4, 'vrsta zelo velike morske živali, po kateri je zaradi podobne oblike dobila ime tudi vrsta vaz za smokve'. 
dovanja, temveč analogija z imenom vrča - orca $(<u ́ p \chi \eta)$, kateremu pa priznava etruščansko posredovanje. ${ }^{17}$

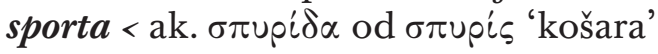

- gr. dolgi v: lat. $\mathbf{u}$ :

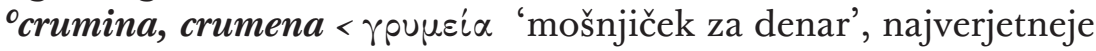
preko etr. *crumina

\section{Po izpadu samoglasnikov v sredinskih zlogih}

- kratki samoglasniki v odprtih zlogih:

Hercle, Hercules <'Hpaxiñ 'Herkul'

'norma < $\gamma \nu \omega \dot{\omega} \mu \nu \alpha$ 'ravnilo, merilo'

orca $<$ o'puץa 'orka'

sporta $<\sigma \pi \cup \rho i \delta \alpha$ 'košara'

oulna < $\dot{\lambda} \lambda_{\varepsilon} \vee \alpha$ 'laket, komolec'

- kratki samoglasniki v zaprtih zlogih:

amurca < ¿́úo $\gamma \alpha$ 'oljne pene'- preko etr. stopnje *amrca /amurca. Najočitnejša kazatelja sta prehoda $\gamma>\mathrm{c}$ ter $\mathrm{o}>\mathrm{u}$.

${ }^{\circ}$ aplustra < $\alpha$ $\varphi \lambda \alpha \sigma \tau o \nu$ 'okras na kljunu ladje'. Slabenje ali izpad kratkega samoglasnika pred skupino $s+$ nezveneči zapornik je sicer zabeleženo tudi v latinščini (npr. miscellus < * minuscellus). V tem primeru bi lahko lat. razvoj iz *aplst-s kasnejšo anaptikso aplust- razložili tudi brez etr. posredovanja.

ospelunca $<\sigma \pi \eta^{\prime} \lambda u \gamma \gamma \alpha$ 'jama, votlina'

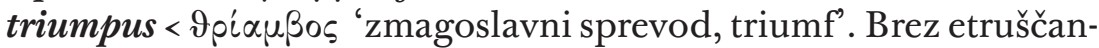
skih glasovnih vplivov bi v latinščini neposredno iz gr. $\vartheta$ piaußos pričakovali *triembus. Etruščanska vmesna stopnja je najbrž bila *triumpe (kot Priumne < Прíuos) - torej zveneč zapornik zamenjan z nezvenečim, kratki $a$ zamenjan $\mathrm{z} u$. Končni $e$ je značilen pri grških samostalnikih o- sklanjatve, ki se v latinščini povrne z -us. Prvič srečamo v latinščini obliko triumpe v Carmen Arvale, kot vzklik ob zmagoslavnih sprevodih gospodarjem. Oblika na -e je morda zvalnik (vokativ),${ }^{18}$ možno pa je tudi, da je kot členica ohranila etruščansko obliko.

- dolgi samoglasniki v odprtih in zaprtih zlogih:

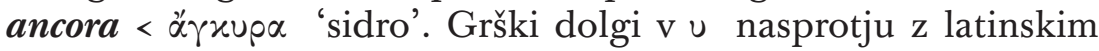
kratkim $o$ se lepo razloži z etruščanskim začetnim naglasom (pri neposrednem prevzemu bi namreč pričakovali v lat. *ancura), preko

$\overline{17}$ Tako tudi A. Ernout v Bulletin de la société linguistique XXX, Les éléments étrusques du vocabolaire latin, str. 121.

${ }^{18}$ de Simone, Die Griechische Entlehnungen im Etruskischen, str. 95. 
etruščanske oblike *ancura s kratkim $u$-jem, ki da v latinščini kratki $o$, kot pri orca in sporta. V etrurščini pa je razvoj najbrž šel naprej in po sinkopi je nastala oblika *ancra. Če je torej beseda prišla v latinščino preko Etruščanov, se je to zgodilo pred izpadom samoglasnika, torej do 5. st. pr. Kr.

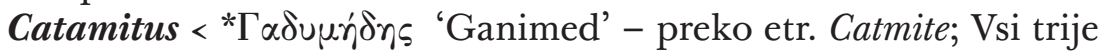
zveneči zaporniki so šli v nezveneče, eta v $i$, končnica $\eta s>\mathrm{e}$. Druga možnost je spremembo $t m<n m$ pripisovati razlikovanju (disimilaciji): $\Gamma \alpha \delta u \mu n ́ \delta$ ns $>$ *Canmite $>$ Catmite ali *Canumite $>$ *Catumite (po razlikovanju $n-m>t-m)>$ Catmite.

lanterna $<\lambda \alpha \mu \pi \tau \hat{\rho} \rho$ 'svetilka, bakla' - skupina $\pi \tau$ se v etrurščini poenostavi: $f t(h t)>t .{ }^{19}$ Možni sta dve razlagi. Obe vključujeta etruščansko posredovanje. Ena je, da je lanterna prišla v latinščino v času, ko etr. $e$ še ni postal $i$, to je najkasneje v drugi polovici 5. st. pr. Kr., kajti iz etruščanske oblike *lantirna, bi tudi v latinščini dobili *lantirna.

Druga možnost je lanterna preko etr. *lantrna $($ erna > rna), vendar za ta razvoj nimamo drugih vzporednih primerov (krajšanje in kasnejši izpad dolgega $e$-ja pred pripornikom $s$ sicer najdemo v primeru Alcsti $<\mathrm{A} \lambda \varkappa \hat{n} \sigma \tau \iota \varsigma)$.

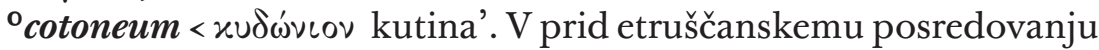
se kažeta prva dva zloga coto- < $\varkappa \cup \delta \omega-$, sporna je končnica -eum.

\section{Po spremembi grških zvenečih zapornikov}

- gr. $\beta$ > lat. $\boldsymbol{p}$ :

triumpus < 9 pi $\alpha \mu \beta o \varsigma^{\prime}$ 'zmagoslavje, zmagoslavni sprevod'

- gr. $\delta$ > lat. $t$ :

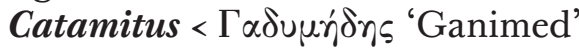

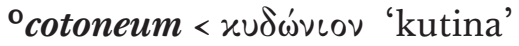

sporta $<\pi u \rho i \delta \alpha$ ' košara'

oxcetra < है $\chi \iota \delta \vee \alpha$ 'kača'20

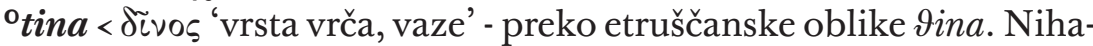
nja med nezvenečimi in pridihnjenimi zaporniki v etrurščini je običajno. Poleg tega so nasprotje med zvenečimi in nepridihnjenimi zaporniki zabrisali jezičniki (likvide), nosniki (nazali) ter priporniki (sibilanti), ki so lahko vplivali tudi na predhodnji zlog, kot v tem primeru. Dolgi $i$ se v etr. ohrani. Za končnico bi sicer pričakovali - $e$ (ki bi v latinščini dal -us), vendar lahko $a$ razložimo po analogiji z drugimi imeni vrčev

\footnotetext{
${ }^{19}$ Italska narečja se ustavijo pri drugi stopnji: $p \rightarrow$ osk. scriftas = lat. scriptas; umbr. screhto $=$ lat. scriptum.

${ }^{20}$ Več v nadaljevanju.
} 
in vaz, tako da je tudi 9 ina padla v kategorijo imen vaz na - a ( kot aska, ulpaia,...). Beseda je sicer izpričana le enkrat pri Varonu. ${ }^{21}$

Proti etruščanskemu posredovanju je etimologija po Hehn-Schradu, kjer je tina alpska beseda (iz skupine tona, tonne).

- gr. $\boldsymbol{\gamma}>$ lat. $\boldsymbol{c}$ :

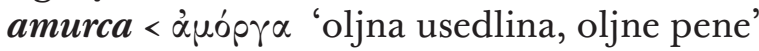

${ }^{\circ}$ cuneus < $\gamma\left(\dot{\omega} v \mathrm{vos}^{\prime}\right.$ 'klin'

${ }^{\circ}$ crumina < $\gamma$ pursia 'mošnjiček za denar'

'orca < öpuץa 'orka'

${ }^{\circ}$ spelunca $<\sigma \pi \eta^{\prime} \lambda u \gamma \gamma \alpha$ 'votlina'

\section{Po končnici}

- -na/ -rna

lanterna $<\lambda \alpha \mu \pi \tau \hat{n} \rho$ 'svetilka'. Dodajaje pridevniške končnice -na na samostalnik je bilo pri Etruščanih v rabi. Imamo namreč primere kot macstrna < lat. magister, malena 'ogledalo', itd. Latinska lanterna je torej sestavljena iz preoblikovane gr. $\lambda \alpha \mu \pi \tau \eta \dot{p}$ in etr. končnice -na.

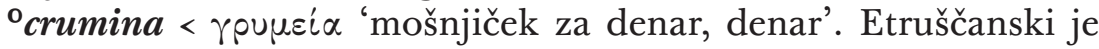
prehod skupine $\gamma \rho>c r$. Naprej pa bi pričakovali razvoj besede * crumea (po zgledu chorea $<\omega \omega p \varepsilon i \alpha$ ). Težavna ostane končnica -ina. Če predpostavljamo, da se je v etr. beseda glasila *crumia $<(\gamma p u \mu \varepsilon i \alpha<$ crumeia $>$ crumea > crumia). Od tod bi s končnico -na nastala oblika *crumiana > crumina (z izpadom $a$ ). Vendar ta razlaga izvzema različico crumena.

Nepojasnjene ostanejo tudi razlike $\mathrm{v}$ pomenu. $\mathrm{V}$ grščini pomeni

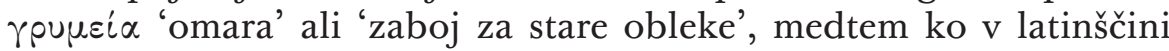
mošnjiček.

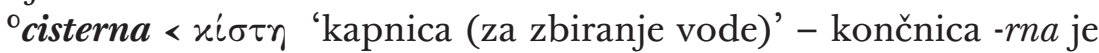
pogosta v etrurščini: VelӨurna, macstrna, taberna,..)

- - tre (-tra)

${ }^{\circ}$ aplustre (a) < $\alpha$ $\varphi \lambda \alpha \sigma \tau o v$ 'okras na kljunu ladje'. Posredovanje za-

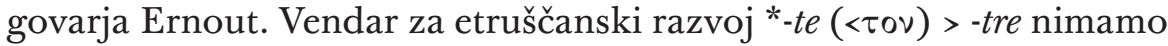
pričevanj. V latinščini sicer imamo lepistra 'posoda za pitje' ter lanistra (poleg lanista) 'gladiator', ki sta etruščanskega izvora.

Končnico -tra najdemo tudi pri lastnih imenih oziroma priimkih (Vitra).

21 'Antiquissimi in conviviis utres vini primo, postea tinas ponebant, id est oris longi cum operculo, aut cupas, tertio amphoras.' Predniki so med gostijami najprej postregli mehove z vinom, nato 'tinas', vrče z visokim vratom in pokrovom, ali 'cupas', $v$ tretje pa amfore.'De vita populi Romani (I, fr. Riposati). 
${ }^{\circ}$ cotoneum / ${ }^{\circ}$ cuneus; končnic -eum / -eus ne moremo pripisati etrurščini. Če pri cuneus predpostavljamo etr. posredovanje preko oblike *cunie < $\gamma(\dot{\omega} v\llcorner o s$, bi nam to v latinščini dalo *cunius; prav tako iz *cutunie $>$ *cotonius. Snovni pridevniki se v latinščini navadno končujejo na -eus (aureus, argenteus); oblika cuneus pa se ni mogla razviti iz *cunius.

\section{Posebni primeri}

\section{1. ${ }^{\circ}$ cocles $<\mathrm{K} u ́ x \lambda \omega \psi$}

Latinska izpeljanka se v tolikšni meri razlikuje od grške predloge, da predpostavljamo bodisi prevzem preko Etruščanov ${ }^{22}$ bodisi samostojen in nepovezan razvoj v latinščini in grščini iz istega indoevropskega korena.

1. Prevzem preko etr. oblike *cuclus, ${ }^{23}$ ki bi latinščini dal cocles. Vendar imamo na napisu iz 4. st. pr. n. št., odkritem v Tarkviniji, ohranjeno

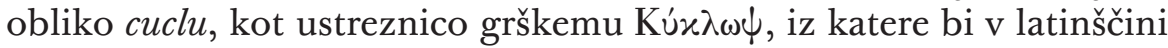
pričakovali cuclo, onis (po III. sklanjatvi). Navadno grška imena, ki se končajo na pripornik, le tega ohranijo tudi v etrurščini (npr. Фuinis, Paris, Rutapis,...), poznamo pa tudi izjeme (npr. Aivas (< "A $\iota_{\mathcal{F}} \alpha \varsigma$ ), ki ga imamo ohranjenega v več različicah: Evas, Eivas in tudi Aiva). V

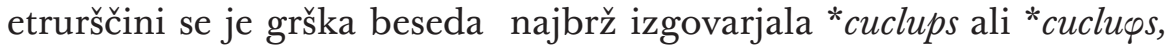
zato je nejasen tudi razvoj *cuclu $\varphi$ s > *cuclus. Oblika *cuclus ostaja pod vprašajem, vendar je tudi prehod iz *cuclus $\mathrm{v}$ cocles, itis, torej v samostalnik III. sklanjatve z osnovo na $-t$, precej nenavaden.

Pisani pa je opozoril tudi na dejstvo, da etr. cuclu ni samo ustreznica gr. Kúx入 $\omega \psi$, temveč je povezan tudi z rodovnim imenom Cuclnie, ki je v rabi z vzdevkom 'enooki', kakor Ceicina < ${ }^{*}$ Caicina ${ }^{*}$ Caice 'slepi'. V latinščini poznamo Cocles kot priimek Horacija, ki je zaustavil prehod Porsenove vojske čez most Sublicia.

Vloga vzdevka cocles v latinščini podpira prevzem od Etruščanov, vendar tudi tukaj ne gre brez oblikoslovnih težav (cocles < cuclu). Poleg tega so Etruščani ga uporabljali tudi kot vzdevek sončnega boga Vulkana.

2. Tudi druga možnost, torej neodvisen razvoj v latinščini in grščini hkrati iz istega indoevropskega korena ${ }^{*} q^{u} e q^{u} l o-o q^{u}$-je težko sprejemljiva. V latinščini naj bi najprej nastala oblika *coclox, rod. * cocloquis > * $c o-$ clicis. Naslednja stopnja bi bila razlikovanje zadnjega $c$ - ja v rodilniku $(c-c: c-t):$ coclitis; od tod prestop imenovalniške oblike po zgledu miles, itis $\mathrm{v}$ cocles, itis.

${ }^{22}$ To tezo zagovarjajo Herbig, Devoto, Ernout, Palmer in drugi.

${ }^{23}$ Devoto, Studi Etruschi. 


\section{2. groma $<\gamma \nu \tilde{\omega} \mu \alpha$}

Ni dvoma, da nosi lat. oblika groma, gruma (cruma) etruščanske sledi, tudi s stališča predmeta samega. Vse, kar je bilo v zvezi z merjenjem zemlje, je spadalo pod naslov Etrusca disciplina in $\mathrm{v}$ tem sklopu prišlo tudi k Rimljanom. Besedo najdemo že pri Eniju v obliki glagola degrumare (forum ). ${ }^{24}$

Jezikovno se prehod iz grščine lepo razloži z etr. posredovanjem:

- nihanje v latinščini med $o, u(<\omega)$

- etruščanska je tudi sprememba $\nu>r$. V skladu s pravili je $\mathrm{v}$ začetnem zlogu skupina muta cum liquida (zapornik + jezičnik) pogosteje zastopana kot muta z nazalom (zapornik + nosnik). Sprememba pa ni potekala le na začetnih zlogih, kajti imamo primere tudi za ostale zloge:

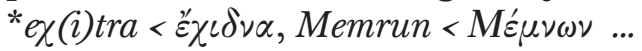

Kot izposojenka iz etr. *cruma, bi v latinščini najprej pričakovali *croma. Ponoven prehod v zveneči zapornik se najbolje razloži z izgovorjavo. Če je v etrurščini izgovorjava nihala med $c r$ - in $\chi^{r-}$, je v latinščini zopet nastopil prvotni $g$. Nezveneči zapornik so namreč v stiku z $r$ izgovarjali pridihnjeno ${ }^{25}$ (torej $\chi$ ruma), kar se v latinščini lahko povrne bodisi z zvenečim (tako primer: etr. Tịile ali Tiple > lat. Tibile), bodisi z nezvenečim (kot pri Vriums $>$ triumpus). Izpričani imamo celo obe različici pri istem imenu: etr. LarYia: lat. LARDIA poleg LARTIA. Po oblikovni strani je torej posredovanje nevprašljivo.

Bolj zapleteno pa je vprašanje, ali izhaja etruščanska ustreznica iz grške osnove $\gamma \nu \tilde{\omega} \mu \alpha$ ali $\gamma \nu \omega \dot{\omega} \mu \omega \nu$. Domnevna etruščanska oblika * crumu (grška imena na - $\omega \nu$ so v etrurščini zastopana $\mathrm{z}-u m /-u n>u$, v nobenem primeru pa ne z-a) bi v latinščini dala * crumo, onis. Notranji razvoj v latinščini * grumo > gruma ${ }^{26}$ pa je vprašljiv. Zato je po oblikovni plati ustreznejša predloga $\gamma \nu \tilde{\omega} \mu \alpha$ (preko etr. ${ }^{*}$ cruma), vendar je s pomenom

${ }^{24}$ An. XVIII, 453.

${ }^{25}$ Prim. str. 44.

${ }^{26}$ Tri etruščanske končnice $-u$ (lat. $o$ ), $-e$ (lat. -us) in - $a$ (lat. $a$ ) so po Devotovi tezi

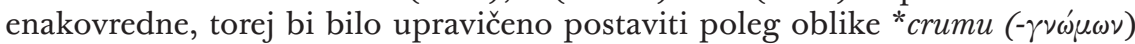
tudi obliko *cruma iz katere bi izšla latinska groma. V etrurščini * crumu ni pridobil določenega spola, kajti izven lastnih imen ne najdemo razlikovanja gramatičnega spola. V odnosu med spoloma v etrurščini in latinščini opazimo naslednje značilnosti (več o tem bi nam lahko povedala etr. rodovna imena, ampak le ta so $\mathrm{v}$ lat. v pridevniški obliki, torej spola ne moremo ločiti; nekaj očitnih nasprotij imamo pri grških lastnih imenih, ki se pojavijo v paru, ko je torej med moškim in ženskim spolom močan kontrast): ena vrsta besed je takih, ki sicer imajo naravni spol, toda nimajo naravnega nasprotja, $v$ tem primeru se v latinščini ohrani le ena oblika; v drugo skupino pa spadajo besede, ki nimajo naravnega spola, zato morajo pasivno sprejeti slovničnega, ki je določen po končnici oblikoslovne kategorije. Cruma naj bi spadala v to skupino. 
zemljemersko sredstvo zabeležena šele v Sudi kot prevod latinske besede gruma. Poleg tega imamo razlago lat. groma pri Pavlu: ${ }^{27}$ groma appellatur genus machinulae cuiusdam, quo regiones agri cuiusque cognosci possunt, quod genus Graeci $\gamma \nu \omega \dot{\mu} \mu \nu \alpha$ dicunt. Izvaja torej iz gr. $\gamma \nu \omega \mu \omega \nu$. Nenazadnje pa sta si grška izraza tudi pomensko zelo blizu.

Kako je $\gamma \nu \tilde{\omega} \mu \alpha$ prišla na etruščanska tla? Izključimo lahko možnost, da so jo Etruščani uporabljali kot abstrakten izraz za znamenje, od koder bi nato prešla v tehnično izrazje. Grški izraz je že prišel v etruščanski jezik kot terminus technicus $\mathrm{v}$ pomenu 'sredstvo za merjenje, vizirni križ'. Nedvomno so ta predmet prevzeli od Grkov. Če bi namreč že imeli lastno napravo, bi imela tudi ime, ki ga najbrž ne bi nadomeščali s tujim.

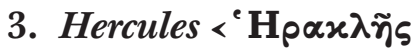

Kult Herkla je bil razširjen med vsemi italskimi ljudstvi. Poleg etruščanske in latinske imamo ohranjeno tudi oskijško različico. Etruščnski primeri Herecele, Hercle, Hercles segajo v prvo četrtino petega stoletja pr. n. št.

Posredovanje Etruščanov je po Devotu upravičeno tako za lat. Hercle $>$ Hercules, kot tudi za oskijško Herclo (Hereclo-). Kazatelj je izpad grškega samoglasnika $(\alpha)$. Poleg tega gredo etr. samostalniki $e$-debla $\mathrm{v}$ italskih jezikih $\mathrm{v} o$-deblo.

Ko je bil v 4. st. pr. n. št. ponovno vpeljan kult ter zgrajen nov tempelj na Circus Flaminius, je prišla tudi nadomestitev oblike Hercle s Hercules. Kajti mnoge grške izposojenke so z okrepitvijo grško-rimskih odnosov na književni ravni, dobile nazaj prvotne končnice (npr. Apollon $<$ Apollo). Hercle se je iz druge preselil v tretjo deklinacijo s končnico -es: ${ }^{*}$ Herclus $>($ o z anaptikso $){ }^{*}$ Hercoles $>$ Hercules.

\section{Proserpina $<\Pi \epsilon \rho \sigma \epsilon \varphi o ́ v \alpha, \Phi \epsilon \rho \sigma \epsilon \varphi o ́ v \alpha$}

Perzefona je zelo pozno prišla v Rim. Njen kult je bil ustanovljen med stoletnimi igrami l. 249 pr. n. št. Igre njej na čast so se odvijale pod imenom ludi Tarentini, kar nakazuje, da je bil kult vpeljan iz Tarenta, vendar jezikovnih sprememb ne moremo razložiti z oskijško ali katerokoli italsko vmesno jezikovno stopnjo. Neposreden prevzem iz grščine bi se najbrž glasil *Persipina. Latinska oblika Proserpina je še najbližja etruščansko-latinski Prosepnai (na napisu, odkritem v Orbetellu, iz konca 4.

${ }^{27}$ Paulus ex Festo, 86 L,'Groma se imenuje vrsta napravice, s pomočjo katere se lahko prepozna meje med ozemlji in ji Grki pravijo $\gamma \nu \omega \mu \omega \nu . '$ 
st. pr. n. št.) ter etruščanskim oblikam $\Phi$ ersipna $2^{28}<{ }^{*} \Phi r s(i) p n a i$. Latinska Proserpina je preoblikovanje Prosepna(i) < etr. ${ }^{*}$ Фrusipnai > * $\Phi$ rs(i)pnai.

Čeprav je bil kult Proserpine vpeljan v Rim komaj v 3. st., lahko domnevamo, da je bilo ime znano že prej, morda preko upodobitev na ogledalih, in je predstavljala osebnost, ki ni bila v nobeni povezvi z grško Perzefono, je pa prevzela njeno ime, ko je prišla v Rim = zamenjava imena.

\section{5. persona $<\pi \rho o ́ \sigma \omega \pi \circ v$}

Persona je najbrž najznačilnejši oziroma največkrat omenjeni prestavnik skupine obravnavanih besed, čeprav niso še rešena vsa vprašanja v zvezi s posredovanji in prehodih skozi tri različne jezike. Neposredno iz grščine vsekakor ni mogoče razložiti latinske oblike. Pri vrstem redu $\pi \rho \circ \delta \omega \pi$ ov > $\varphi$ ersu > persona pa je potrebno natančneje pregledati posamezne prehode.

- $\pi \rho o ́ \sigma \omega \pi \circ \nu>\varphi$ ersu:

Napis $\varphi$ ersu se pojavlja ob moških podobah, ki nosijo masko, na freskah štirih grobnic v Tarkviniji, vse iz 6. st. pr. n. št., in sicer dvakrat v vlogi rablja (Tomba degli Auguri in Tomba delle Olimpiadi), kot tekač (Tomba degli Auguri) in kot plesalec (Tomba della Pulcinella). Na vseh slikah ima podoba na obrazu masko $\mathrm{z}$ brado in špičasto kapuco. Da bi bila noša neposredno povezana $\mathrm{z}$ vlogo, ni najbolj verjetno, saj sta rabelj (Tomba delle Olimpiadi) ter plesalec enako oblečena, ostala dva različno. Vseeno pa ni dvoma, da je obstajalo več vrst $\varphi$ ersu. Najbrž so na pogrebnih igrah ter raznih praznikih igrali različne mimične vloge.

Prehod $\pi \rho \circ->\varphi e r$ - (kot pri Proserpini) je v etrurščini nastal iz vmesne stopnje * $p r$ - . Pridihnjeni zapornik $\varphi$ se lepo razloži z bližino $r$-ja: per- $(<\pi \varepsilon \rho)>{ }^{*}$ pr- $>\varphi r$. Težje je razložiti drugi del $-s u$, kajti kvečjemu bi pričakovali * $\varphi$ ersupe ali *prusupe.

Obstaja več grških predlog kot ${ }^{*} \pi \rho \circ \sigma \omega \psi^{29}$ kar bi dalo etruščansko obliko * prsu ali epsko množinsko obliko $\pi \rho \circ \sigma \omega \dot{\omega} \pi \alpha \tau \alpha,{ }^{30}$ katere edninske oblike bi morebiti bile * $\pi \rho \circ \sigma \dot{\omega} \pi \alpha \rho$ ali * $\pi \rho \circ \sigma \omega ́ \pi v$ vendar bi s težavo pri obeh izpeljali etr. obliko $\varphi$ ersu.

Poleg tega je težava $\mathrm{v}$ pomenskem prenosu, kajti gr. $\pi \rho o ́ \sigma \omega \pi$ ov $\mathrm{v}$ pomenu 'maska' dobimo prvič šele pri Aristotelu ${ }^{31}$ in nato Demostenu.

\footnotetext{
${ }^{28}$ Pripona $i$, s katero so poudarjali ženski spol kot nasprotje njene moške polovice, Hada $=$ Aita $(<$ Aínns) .

${ }^{29}$ Ribezzo.

${ }^{30}$ H 212, $\sigma 192$.

${ }^{31}$ Po. $1449^{a}$ 36, b 4; Prob. $958^{a} 17$.
} 
Pri Homerju ima $\pi \rho o ́ \sigma \omega \pi$ ov pomen 'figura, izgled'. Ali je torej možno, da bi tehnični izraz iz dramskega okolja prišel v Etrurijo že v 6. st. pr. n. št?

Na Peloponezu so sicer našli maske človeških obrazov iz tega obdobja. Potrebno pa bi bilo natančno, z zgodovinkega stališča pretehtati možnost, da bi kultne maske prišle k Etruščanom s Peloponeza.

Vpliv jonske umetnosti je jasen in prepoznaven v grobnici Tomba degli Auguri. Tudi v stari atiški komediji se najdejo maske, tudi s čepicami, vendar se časovno ne ujemajo.

Odnos $\Phi$ ersu > persona: Čeprav je bilo predlaganih veliko rešitev, je danes najbolj priznana ugotovitev, da je latinska oblika prevzeta od etruščanske $\varphi$ ersuna: torej s končnico -na, ki v etrurščini služi tvorjenju pridevnikov, ki zaznamujejo pripadnost. Tako v rodovni imenih oziroma priimkih, kakor tudi za tvorjenje pridevnikov iz samostalnikov (npr. su9i 'grob' > su९ina 'kar spada h grobu'; ali aska eleivana 'vrsta

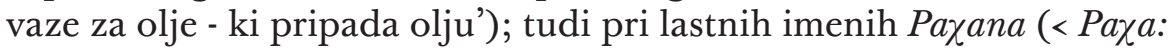
Bachus, ki pripada Bakhu, bakhovski).

* ersuna je najbrž bila oprema, ki spada k $\varphi$ ersu, kar mu pripada. Фersuna torej ni majhna maska, kot so nekateri označevali. Tudi spol v etrurščini ni določen, saj ni posebej zaznamovala spola. V latinščini je šla v prvo sklanjatev, ker se končuje na - $a$.

Pomen, ki ga je dejansko imel $\varphi$ ersu v etrurščini je zavit v temo. Imel je vlogo apelativa. Zagotovo vemo tudi, da je bil nomen agentis, ter, da se je kasnejši pomen 'maska' razvil iz pridevnika * $\varphi$ ersuna.

Naslednje vprašanje je, kako je torej ழersuna prišla v Rim. Ena možnost je, da skupaj z gladiatorskimi igrami v 3. st. pr. Kr. Livij pa poroča, da so prvi gledališki rekviti prišli v Rim iz Etrurije leta 364 in sicer so to bili plesalci in glasbeniki z religiozno funkcijo. Šele kasneje da so postali gledališki igralci in se imenovali histriones. $\mathrm{V}$ tem primeru persona najbrž ni imela prvotnega pomena - gledališka maska. Verjetneje je, da je beseda prišla v latinščino že kot tehnični izraz gledališča oziroma gledališke opreme (igralčeva maska). Kot posrednica pa se zdi najverjetnejša atelana, ki so jo v Rim vpeljali Oski, kot pravi Pavel: ${ }^{32}$ per Atellanos, qui proprie vocantur personati.

\section{6. ${ }^{\circ}$ littera $<\delta \iota \varphi \vartheta \in ́ \rho \alpha$}

Pri Hezihiju najdemo kot gloso razloženo sestavljenko: $\delta \iota \varphi \vartheta \varepsilon \rho \alpha ́ \lambda$ o८-

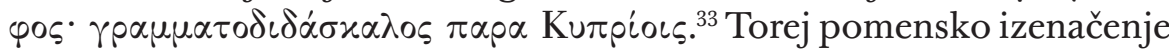

${ }^{32}$ Ex Festo 238 L.

33 'učitelj pisanja pri Ciprčanih'. 


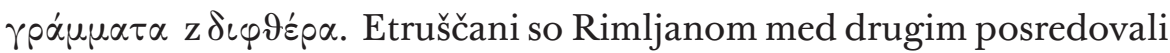
tudi druge izraze v zvezi s pisanjem (elementum - prvotno 'črka'; stylus - 'pisalo'). Prehod $\delta>l$ lahko razložimo, saj imamo podoben primer v latinščini: $\delta \alpha \dot{x}$ pu $\mu \alpha>$ lacrima. Tudi prehod $\varphi \vartheta(\mathrm{pt})>t t$ je možen.

Po drugi razlagi naj bi se littera razvila iz lites- $a>$ litera, kot opera > opus-a.

\section{7. ${ }^{\circ}$ excetra $<e^{\prime} \chi\llcorner\delta \vee \alpha$}

V etrurščini je pričakovati ustreznico: *exitra (< * exitna); za latinsko obliko excetra sta možni dve rešitvi:

1.) e v exetra je drugoten, vrinjen šele $\mathrm{v}$ latinščini, torej iz razvoja *extra (po izpadu sredinskega vokala) > *eetra > lat. excetra;

2.) Izposojenka je iz časa, ko se izpad oziroma oslabitev samoglasnikov v sredinskih zlogih še ni začela (pred koncem 5. st. pr. n. št.), torej je grški $\iota \mathrm{v}$ etrurščini obravnavan kot glas, ki je v latinščini dal $e$

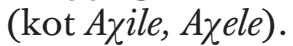

V latinščini se excetra prvič pojavi pri Plautu:" 'nam cum leone, cum excetra, cum apro aetolico ... deluctari mavelim'. Kljub napačnim etimologijam antičnih piscev (npr. Servijeva: excetra dicitur, quod uno caeso tria capita excrescebant), ${ }^{35}$ je imela beseda tuj zven in je dajala vtis narobe zložene.

\section{Zaključek}

Skupna značilnost vseh besed z etruščanskim posredovanjem torej je, da so vse imena za predmete in bitja (v glavnem bogove), ne pa pojme. Kot smo videli v primeru excetra, so jo ob prevzemu iz grščine tako Grki in Etruščani kot Rimljani še razumeli kot strahovito pošast pri Rimljanih se je s tem pomenom uporabljala še za časa Plauta. Šele takrat dobimo posamezne primere, ko so izraz uporabili v prenesenem pomenu za zmerjanje z 'vipero, kačo', tako, da je slabšalni prizvok prevladal.

Podoben primer je persona, za katero gotovo ne moremo reči, da so jo Etruščani in Rimljani v 5. ali 4. st. pr. n. št. razumeli kako drugače kot del opreme igralca za gledališko vlogo.

\footnotetext{
${ }^{34}$ Pers. 3, 'kajti raje bi se bojeval z levom, s kačo, z etolskim merjascem'.

${ }^{35}$ ad Aen. VI, 287, 'reče se excetra, ker so po eni odsekani glavi zrasle tri'.
} 


\section{The Etruscan Language as an Intermediary in the Import of Greek Words into Latin}

Summary

The commercial and cultural contacts of the Etruscans with their Greek neighbours are reflected in the Etruscan vocabulary. The preserved inscriptions reveal a number of Greek mythological names, as well as words referring to pottery and drinking vessels. These transcriptions are invaluable to the study of the Etruscan language (especially its phonology) and its almost eight-century-long development. In the light of their influence on Rome (including the introduction of the alphabet), the Etruscans can be assumed to have passed on certain Greek words as well.

The main signs that a Greek word was transmitted into Latin via Etruscan are:

- the absence of the vowel $o$ : the Etruscans used a single letter (Y, later the variant $\mathrm{V})$ for four different Greek vowels $(0, \omega$, and the long and short $\mathrm{u})$. In Latin, the short vowels normally changed back to $o$, whereas the long ones could remain $o$ or $u$;

- the absence of the voiced stops $b, d, g$, which are represented by $p, t, c$ in Etruscan;

- the gradual weakening and loss of the vowels in medial syllables as a result of the stress shift in the fifth century B. C. The stress was shifted to the initial syllable.

- the Etruscan endings - na and -tre (-tra).

Considering the above-mentioned characteristics, Etruscan could have been instrumental in transmitting into Latin words like orca (<

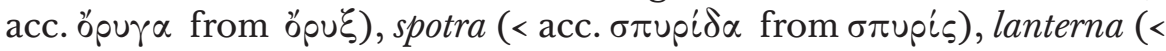

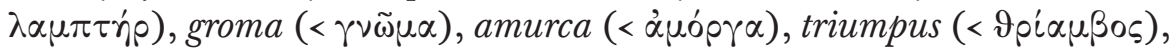

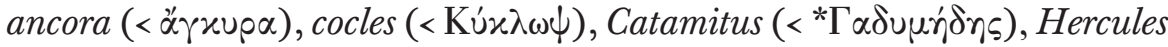

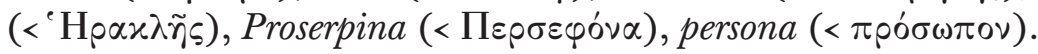

There are many other Latin words which show characteristics typical of Etruscan. However, we must avoid hasty conclusions since the meaning of the same word in Greek and Latin often differs. An additional difficulty is the fact that many Etruscan forms are not preserved but only hypothetical.

\section{LITERATURA}

BLOCH, R., Les Étrusques, Paris (1956)

BONFANTE, G. in L., Lingua e cultura degli Etruschi, Roma (1985) 
BONFANTE, G., Le tenui e le aspirate Etrusche. Studi Etruschi, LXIV (1998)

BONFANTE, L., Etruscan dress, Baltimore \& London (1975)

BUCK, C., Comparative Grammar of Greek and Latin, Chicago (1962)

COLONNA, G., Nomi etruschi di vasi. Archeologia classica, XXV - XXVI $(1973-74)$

CRISTOFANI, M., Gli Etruschi, cultura e societa, Novara (1985)

De SIMONE, G., Die griechische Entlehnungen im Etruskischen, 2. del, Wiesbaden $(1968-70)$

DEVOTO,G., L'etrusco come intermediario di parole greche in latino. Studi Etruschi, II (1928-29)

DOKLER, A., Grško-slovenski slovar, Ljubljana (1915)

ERNOUT, A.-MEILlET, A., Dictionnaire étymologique de la langue latine, Paris (1951)

GROŠELJ, M., Etyma latina (norma). Živa antika 4 (1954)

KOPRIVA, S., Latinska slovnica, Maribor (1989)

LIDDELL, H. G.-SCOTT, R., A Greek-English Lexicon, Oxford (1996)

PALLOTINO, M., Etruscologia, Milano (1968)

PALLOTINO, M., La storia della prima Italia, Milano (1984)

PALMER, L. R., La lingua latina, Torino (1977)

PISANI, V., Storia della lingua latina, 1. del, Torino (1962)

RIX, H., Das etruskische Cognomen, Wiesbaden (1963)

WALDE, A.-HOFMANN, J. B., Lateinisches etymologisches Wörterbuch, Heidelberg (1938-56).

WIESTHALER, F., Latinsko-slovenski slovar, vol. I - IV, Ljubljana

Naslov:

Tina Silič

e-mail:tsilic@volja.net

Filozofska fakulteta

Oddelek za klasično filologijo

Aškerčeva c. 2

SI-1000 Ljubljana 